\title{
THIN-LAYER DRYING FROM WASTES POMEGRANATE PEEL
}

\section{Gomaa G. Abd El-Wahhab ${ }^{1 \&^{*}}$ and Elwan A. Darwish ${ }^{2}$}

${ }^{1}$ Assist. Prof., Ag. Cons. Eng. and Environ. Control. Dept., Fac. of Ag. Eng., Al-Azhar U., Cairo, Egypt.

${ }^{2}$ Assist. Prof., Ag. Products Processing Eng. Dept., Fac. of Ag. Eng., Al-Azhar U., Cairo, Egypt.

*galal_gomaa@azhar.edu.eg

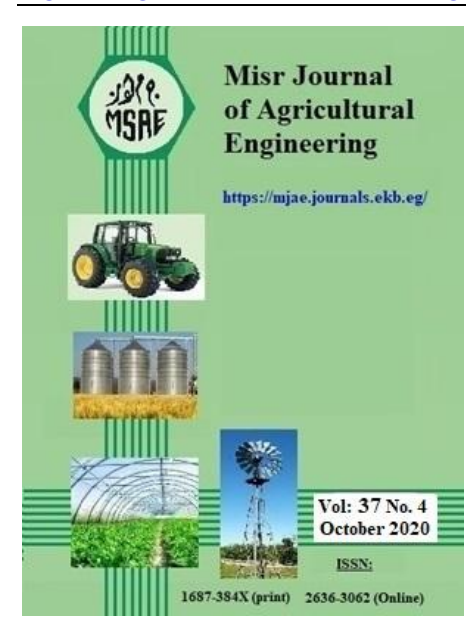

(C) Misr J. Ag. Eng. (MJAE)

\section{ABSTRACT}

Pomegranate juice processing produces a large amount of peel as a by-product or waste which is a potential source of raw material for food and other bioprocessing industries, such as(fights acne, pimples and rashes, helps in detoxification of body, cures sore throats and coughs, arrests hair loss and prevents dandruff, improves dental hygiene). Drying the peel offers opportunities for value addition into novel products, thus reducing amount of produced waste from the fruit processing operations. The dry parameter was drying air temperature (65, 75 and $\left.85^{\circ} \mathrm{C}\right)$ and drying air velocity $(1,2$ and $3 \mathrm{~m} / \mathrm{s}$ ) at layer thickness of $7 \mathrm{~mm}$. The results indicated that the initial moisture content of $244 \%$ (d.b) decreased to a range between 6 and $4 \%$ (d.b) at the end of drying process depending on the drying conditions. The results obtained show that moisture content of the

\section{Keywords:}

Thin layer drying, pomegranate peel, by-product, wastes. by-product decreases with time and temperature. Two thin-layer drying models were selected to describe experimental drying kinetics data. The models were compared based on their coefficients of determination $\left(R^{2}\right)$, reduced chi square $\left(\chi^{2}\right)$ and root mean square error (RMSE) between Observed and predicted moisture ratios. On the other hands, the calculated operation cost of the dryer approaches about $5.5 \mathrm{E} / \mathrm{kg}$, while the price of $1 \mathrm{~kg}$ of dried pomegranate peel is $35 \mathrm{LE}$ in the market.

\section{INTRODUCTION}

$\mathrm{P}$ omegranate fruit ( Punica granatum L.) belongs to the Punicaceae family. Commercial orchards of pomegranate are grown in countries such as Iran, India, Egypt, China, Israel, Tunisia, Syria, Lebanon, Turkey, Greece, Cyprus, Italy, France, Spain, Chile, Portugal, USA, Oman and most recently in South Africa (Fawole et al., 2012). The fruit is comprised of peels and arils (which contain juice and seeds/kernels) sacs. Total Egyptian Pomegranate production of about $382 \mathrm{~T}$ g (Ministry Of Agriculture, 2019) During juice processing, the peel is a major by-product and accounts for about 50\% of whole fruit mass (Fawole et al.,2015). Pomegranate juice processing produces large amount of peel as by-product or waste which is a potential source of raw material for food and other bioprocessing industries, such as (fights acne, pimples and rashes, helps in detoxification of body, cures sore throats and coughs, arrests 
hair loss and prevents dandruff, improves dental hygiene). Drying the peel offers opportunities for value addition into novel products, thus reducing waste from the fruit processing operations (Mphahlele et al., 2019). Pomegranate is composed of 3 parts: seeds, juice, and peels. Pomegranate peel is an inedible part/byproduct obtained during processing of pomegranate juice. It is characterized by the presence of flavonoids and tannins which have been associated with many of the biological properties demonstrated by the peel (Faria and Calhau, 2010). Fresh pomegranate biomass contains high levels of moisture and soluble sugars (Shabtay $\boldsymbol{e t}$ al., 2008). Generally processing one ton of pomegranate fruits yields approximately from 322 to 341 liters of juice and generates about $669 \mathrm{~kg}$ of pomegranate by-products made of pith, rinds, and peels. In fresh weight, the peel and internal membranes of the pomegranate represents 50\% ( Hasnaoui et al., 2014). The process of pomegranate juice production remains large quantities of pomegranate by-products such as peels and seeds: causing serious environmental pollution as well as acting as a substrate for insect and microbial proliferation. The processed pomegranate seeds have generally high moisture contents, and need removal of moisture before the production of high value-added products such as dietary fiber, flavonoids, phenolic acids and bio-oil (Viuda-Martos et al. 2012). Drying is a process of removing moisture from wet materials and it is an important technique for the processing and preservation of agricultural products. The demand for highquality dried products is increasing all over the world. The main purpose of drying products is to allow longer periods of storage, minimize packaging requirements and reduce shipping weights (Zielinska and Markowski 2010). There are many drying methods, of which sun drying is the most traditional and economical one. However, sun drying has some significant disadvantages, such as the fact that it is time-consuming, weather dependent, results in nutrient loss, is labor intensive and may result in possible environmental contamination (Chen et al. 2013). If it can not used by farmers and industries as well as medical activities cause serious environmental problems. Drying experiments were performed at constant air velocity of $2.0 \mathrm{~m} / \mathrm{s}$ and initial thickness of $2.8 \mathrm{~cm}$ for pomegranate peels, and 3 drying air temperatures of 50,60 , and $70^{\circ} \mathrm{C}$. The drying time decreased with increase in drying air temperature (Doymaz, 2011). The mathematical models of thin layer drying behaviour of pomegranate peels (initial thickness $5.00 \pm 0.05 \mathrm{~mm}$ and moisture content $70.30 \%$ wet basis) using three air temperatures $\left(40,50\right.$ and $\left.60^{\circ} \mathrm{C}\right)$ at a constant air velocity of $1.0 \mathrm{~m} / \mathrm{s}$. The results obtained showed that drying time decreased as the oven drying temperature increased. The drying process took place mainly in the falling rate period (Mphahlele, et al., 2019). The processed pomegranate peels have generally high moisture contents (around 70.1\%,w.b.), and need to removal of moisture before the production of high-added value products such as flavonoids and tannins. Drying has always been of great importance to the preservation of agricultural products and by products.

\section{The main objectives of this study were:}

-A study thin-layer drying characteristics of pomegranate by-products using the thermal dryer at different air temperature and hot air velocity.

-Chemical analysis pomegranate by-products.

- Estimate drying cost of the dried pomegranate by-products. 


\section{MATERIALS AND METHODS}

\section{Pomegranate fruit peel:}

Fresh pomegranate fruits (Punica granatum L.) were obtained from the local market. Mature pomegranate fruits were washed and cut manually to separate the seeds and peel. The rind (peels) thus obtained, cut into small pieces using a sharp knife. The peels were manually separated from the fruits and then it was minced in a blender. Pomegranate peels minced had an initial moisture content of $70.1 \%$ (w.b.), which was determined according to the AOAC (Association Of Official Analytical Chemists).

\section{Experimental Apparatus:}

This unit was developed, constructed by Abd El-Wahhab (2015), Faculty Agricultural Engineering, Al-Azhar University, Nasr City, Cairo, Egypt. The dryer was fitted with a temperature control system, as shown in Fig. 1.

1. Forced air section: A small air blower of $300 \mathrm{~W}, 220 \mathrm{~V}$, made in China was used to supply the hot air flow rate. This blower connected to the air heating section.

2. Air control gate: Section of the steel sheet thickness of $10 \mathrm{~mm}$ moving up and down through the spiral nail to pass the amount of air required.

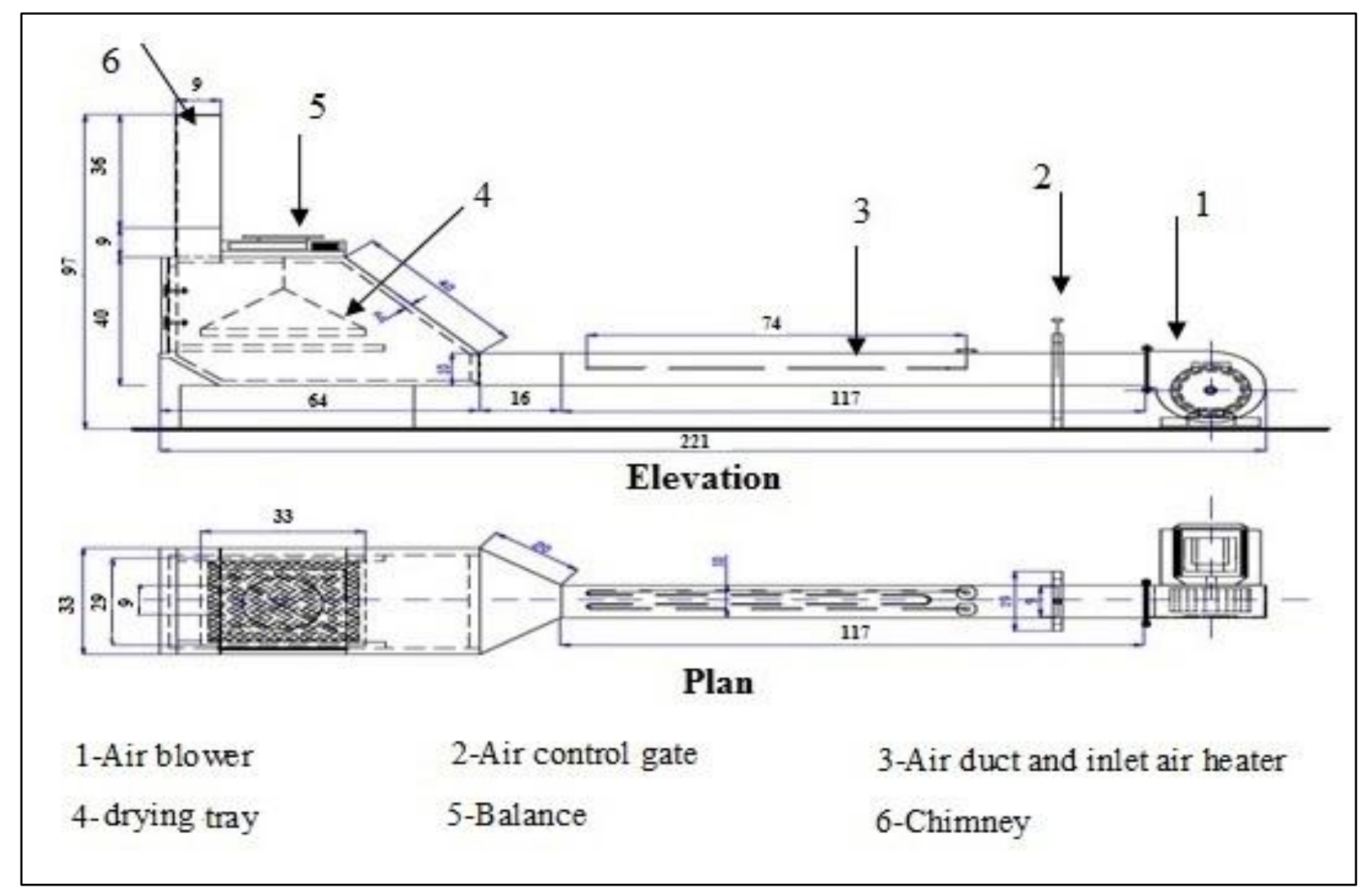

Fig. (1): Elevation and plan of unit drying (Dimension $(\mathrm{cm})$ ).

3. Tray drying: Made of a fixed aperture wire mesh of galvanized steel for entering hot air to product parts, dimensions of $330 \times 270 \mathrm{~mm}$ framed of wood thickness of $30 \mathrm{~mm}$ rectangular shape.

4. Air heating section: Room with dimensions of 1300mm length, $100 \mathrm{~mm}$ width, $100 \mathrm{~mm}$ high made of galvanized steel sheet of $0.5 \mathrm{~mm}$ thickness and insulated from the outside by glass 
wool with thickness of $30 \mathrm{~mm}$ to prevent heat loss. The electrical heater of $3 \mathrm{~kW}$ (U form) was fixed inside the housing to heat the drying air.

5. Drying section: The drying chamber was constructed of wooden panels 400x330x300 mm (20mm thick), the side walls and bottom of drying chamber were insulated by foam layer. Drying air inters the chamber after leaving air heating section through an air duct from the bottom to the top of the dryer bin. The dryer door was made of wooden panels with dimensions of $330 \mathrm{~mm}$ long and $300 \mathrm{~mm}$ wide, the door was connecting to drying chamber by two hinges and tightly sealed by a rubber gasket during the drying process. Drying was mounted on a wooden stand of $800 \mathrm{~mm}$ height from the ground.

\section{Measurement instruments:}

1. Digital veneer caliper: To measure dimensions (Accuracy of $0.01 \mathrm{~mm}$ ).

2. Electric oven: with the following specifications (VENTICELL55 type, 230V, 50/60 Hz, $1250 \mathrm{w}, 250 \mathrm{Max}$.tempruture) is used to determine the moisture content of by- products samples, at $105^{\circ} \mathrm{C}$ for 24 hour drying time.

3. Anemometer: To measured air velocity inside the drying chamber (Range from 0 to $44 \mathrm{~m} / \mathrm{s}$, accuracy of $0.1 \mathrm{~m} / \mathrm{s})$.

4. A digital balance was used for measuring the weight of the sample of by-products during drying ( $5 \mathrm{~kg}$ with sensitivity of $0.1 \mathrm{~g}$ ).

5. Temperature control device: Is connected to the temperature sensor inside the drying chamber for temperature sensor drying air temperature. This sensor is connected to a digital thermostat. Digital thermometers (a type of Dixell, not a model "XR10CX - 5N0C0" with accuracy of $0.1^{\circ} \mathrm{C}$ ). The sensitivity ranged from 0.1 to $2^{\circ} \mathrm{Cand}$ work in a temperature range of $0-400{ }^{\circ} \mathrm{C}$.

4. Experimental Procedure:

Drying experiments were performed at drying temperatures $(65,75$ and 85$) \mathrm{C}$ and a air velocity of $(1,2$ and 3$) \mathrm{m} / \mathrm{s}$ for all samples. the samples were distributed uniformly into the square chamber as a thin layer (layer thickness: $0.8 \mathrm{~cm}$ ). Each experiment utilized in the experiment weighed $244 \mathrm{~g}$. Sample weight was recorded at regular time intervals (30 min). Drying process was finished when the moisture content of the samples was about $2 \%$ (w.b.). The dried product was cooled and packed in low-density polyethylene bags that were heat sealed. The drying experiments

5. Mathematical Modeling of Drying Curves:

1. Initial moisture content of samples

Initial moisture content of samples was determined by oven at temperature of $105^{\circ} \mathrm{C}$ for 24 hours (AOAC Standards, 2005). It can be calculated as follows:

$$
M_{i d}=\frac{W_{m}}{W_{d}} \times 100
$$

Where:

$\boldsymbol{M}_{\boldsymbol{i d}}=$ Moisture content dry basis (\%).

$\boldsymbol{W}_{\boldsymbol{m}}=$ Mass of water in sample $(\mathrm{g})$.

$\boldsymbol{W}_{\boldsymbol{d}}=$ Mass of dry material $(\mathrm{g})$.

2. Moisture content $\left(\mathbf{M}_{\mathrm{t}}\right)$, (dry basis \%):

The moisture content, dry basis \% is determined every 30 minutes as follows (Tayel, et al., 2012): 


$$
M_{t}=\frac{B-\grave{A}}{\grave{A}}
$$

Where:

$\boldsymbol{A}^{\prime}=$ Mass of dry sample (g).

$\boldsymbol{A}=$ Mass of fresh sample (g).

$\boldsymbol{B}=$ Mass of sample at any time $(\mathrm{g})$.

3. Moisture ratio $(\mathrm{MR})(\mathrm{db} \%)$.

The moisture content of dried sample at time $t$ can be transformed to moisture ratio (MR) (Tayel, et al., 2012):

$$
M R=\frac{M_{t}-M_{e}}{M_{i}-M_{e}}
$$

\section{Where:}

$\mathbf{M}_{\mathrm{i}}$ : Initial moisture content, \% (db).

$\mathbf{M}_{\mathrm{t}}$ : Moisture content at any time during drying, $\%(\mathrm{db})$.

Me: Equilibrium moisture content, \% (db).

Table (1) thin-layer drying models applied to the drying curves of pomegranate peel.

\begin{tabular}{|c|c|c|}
\hline Model & Mathematical equation & Reference \\
\hline Lewis & $\mathrm{MR}=\exp (-\mathrm{kt})$ & Lewis (1921) \\
\hline Henderson and Pabis & $\mathrm{MR}=\mathrm{a} \exp (-\mathrm{kt})$ & Henderson and Pabis([1961) \\
\hline
\end{tabular}

\section{Data Analysis}

The drying data obtained were fitted to thin-layer drying two models detailed in Table (1). The coefficient of determination $\left(\mathrm{R}^{2}\right)$ is one of the primary criteria for selecting the best model to define the drying curves. In addition to $\mathrm{R}^{2}$, reduced chi-square $\left(\chi^{2}\right)$ and root mean square error(RMSE) are used to determine the quality of the fit.

These parameters can be calculated as follows:

$$
\begin{aligned}
& x^{2}=\frac{\sum_{i=1}^{N}\left(M R_{O b s . i}-M R_{p e r . ~}\right)^{2}}{N-Z} . \\
& R M S E=\left(\frac{\sum_{i=1}^{N}\left(M R_{O b s . i}-M R_{p e r . i}\right)^{2}}{N}\right)^{0.5}
\end{aligned}
$$

Where:

$\boldsymbol{M R}_{\boldsymbol{O b s . i} \boldsymbol{i}}:$ is Observed dimensionless moisture ratio;

$\boldsymbol{M R}_{\text {Per. } \boldsymbol{i}}$ : is predicted dimensionless moisture ratio;

$\mathrm{N}$ : isnumber of observations;

$\mathrm{Z}$ : is the number of constants.

The best model describing the drying characteristics of samples was chosen as the one with the highest R2, the lowest $\chi 2$ and RMSE (Perea-Flores et al. 2012; Karaaslan et al. 2013).

5. Cost analysis: The dryer hourly costs were calculated based on the fixed costs and variable costs of convection dryer by using the following formula (Awady et al., 2003)

$$
\boldsymbol{C}=\frac{P}{h}\left(\frac{\mathbf{1}}{a}+\frac{i}{2}+t+r\right)+(W . e)+\frac{m}{\mathbf{2 0 0}}
$$

Where: $\mathbf{C}=$ Dryer hourly cost, L.E. $/ \mathrm{h}, \boldsymbol{P}=$ Price of dryer, L.E., =500 L.E, $\mathbf{h}=$ Yearly working hours, which were is assumed in the present work to be:(300 day/year x 2 period/day x 8 $\mathrm{h} /$ period $=4800 \mathrm{~h} /$ year $), \boldsymbol{a}=$ Life expectancy of machine, about (10 Year), $\boldsymbol{i}=$ Interest 
rate/Year. (The bank interest in Egypt), which was about 14\%, $\boldsymbol{t}=$ Taxes and overheads ratio, which is assumed in the present work to be $20 \%, r=$ Repair and maintenance ratio, which is assumed in the present work $10 \%$., $\boldsymbol{W}=$ Power of dryer $(\mathrm{kW}), \boldsymbol{e}=$ Hourly cost $/ \mathrm{kW} . \mathrm{h},(0.65$ L.E./kW. h), $\mathbf{m}=$ The monthly average wage, L.E., (1800 L.E), impose that here are 10 dryers becomes (180 L.E./man. dryer, month), $\mathbf{2 0 0}=$ The monthly average working hours. $=0.9+0.049+0.9=0.98$

$$
\operatorname{Cost}\left(\mathrm{L} . \mathrm{E} / \mathrm{Kg} \mathrm{g}_{\text {dried product }}\right)=\frac{\text { Dryer hourly } \operatorname{cost}(\mathrm{L} . \mathrm{E} / \mathrm{h})}{\operatorname{Dryer} \text { productivity }\left(\mathrm{kg}_{\text {dried product }} / \mathrm{h}\right)}
$$

\section{RESULTS AND DISCUSSION}

\section{Analysis of Drying Curves:}

The effect of air temperature and air velocity on moisture content is shown in Fig. (1). The moisture content decreased exponentially with increasing duration of drying time. As expected, the air temperature and air velocity had a significant effect on the moisture content of the pomegranate by-products. The results showed that drying time decreased greatly when the air temperature and air velocity increased. The decreased moisture content could be attributed to increased evaporation of water both on the surface and in the by-products due to increasing temperatures and velocities of drying air. Fig. (1) shows that the moisture content of $244 \%$ (db) decreased to rang between 6 and $4 \%(\mathrm{db})$ at the end drying process depending on the drying conditions. For instance, the shortest drying time was recorded at $150 \mathrm{~min}$ with $85^{\circ} \mathrm{C}$ drying air temperature and $3 \mathrm{~m} / \mathrm{s}$ air velocity. While, the longest drying time was recorded at $450 \mathrm{~min}$ with $65^{\circ} \mathrm{C}$ and $1 \mathrm{~m} / \mathrm{s}$ air velocity.

TABLE (2) results of statistical analysis on the thin-layer drying models for drying of pomegranate peel.

\begin{tabular}{|c|c|c|c|c|c|c|c|}
\hline \multicolumn{2}{|c|}{ Model } & \multicolumn{3}{|c|}{ Lewis } & \multicolumn{3}{|c|}{ Henderson and Pabis } \\
\hline $\begin{array}{c}\text { Temperat } \\
\text { ure }{ }^{\circ} \mathbf{C}\end{array}$ & $\begin{array}{c}\text { Veloc } \\
\text { ity } \\
\text { m/s }\end{array}$ & $\mathbf{R}^{2}$ & $\chi^{2}$ & RMSE & $\mathbf{R}^{2}$ & $\chi^{2}$ & RMSE \\
\hline \multirow{3}{*}{65} & 1 & 0.993 & $6.7 \mathrm{E}-14$ & $2.4 \mathrm{E}-07$ & 0.997 & $1.2 \mathrm{E}-33$ & $3.29 \mathrm{E}-17$ \\
\hline & 2 & 0.998 & $5.3 \mathrm{E}-33$ & $6.67 \mathrm{E}-17$ & 0.997 & $1.3 \mathrm{E}-34$ & $1.06 \mathrm{E}-17$ \\
\hline & 3 & 0.987 & $4.2 \mathrm{E}-13$ & 5.88E-07 & 0.989 & $4.5 \mathrm{E}-34$ & $1.93 \mathrm{E}-17$ \\
\hline \multirow{3}{*}{75} & 1 & 1 & 8.6E-14 & $2.69 \mathrm{E}-07$ & 1 & 4.4E-34 & $1.92 \mathrm{E}-17$ \\
\hline & 2 & 0.997 & 2.1E-08 & 0.00013 & 0.995 & $5.5 \mathrm{E}-34$ & $2.08 \mathrm{E}-17$ \\
\hline & 3 & 1 & $2.9 \mathrm{E}-34$ & $1.49 \mathrm{E}-17$ & 1 & $1.7 \mathrm{E}-34$ & $1.15 \mathrm{E}-17$ \\
\hline \multirow{3}{*}{85} & 1 & 0.995 & $1.1 \mathrm{E}-13$ & $2.91 \mathrm{E}-07$ & 0.996 & $1.4 \mathrm{E}-34$ & $1.07 \mathrm{E}-17$ \\
\hline & 2 & 1 & $6.7 \mathrm{E}-34$ & $2.28 \mathrm{E}-17$ & 1 & $1.9 \mathrm{E}-33$ & $6.74 \mathrm{E}-34$ \\
\hline & 3 & 1 & $2.7 \mathrm{E}-32$ & $1.36 \mathrm{E}-16$ & 1 & $8.3 \mathrm{E}-32$ & $2.35 \mathrm{E}-17$ \\
\hline
\end{tabular}




\section{Fitting of Drying Curves:}

The moisture content data obtained at different air temperatures and air velocity were converted to dimensionless MR and then fitted to the thin-layer drying two models in Table (1). The statistical results from models are summarized in Tables (2). The best model describing the thin-layer drying characteristics of pomegranate peel were chosen as the one with the highest $\mathrm{R}^{2}$ values and the lowest $\chi^{2}$ and RMSE values. The statistical parameter estimations showed that $\mathrm{R}^{2}, \chi^{2}$ and $\mathrm{RMSE}$ values were ranged from 0.987 to 1 , from $1.3 \mathrm{E}-34$ to $2.1 \mathrm{E}-08$, and from 6.74E-34 to 0.00013, respectively. Of all the models tested, the Henderson and Pabis. model gives the highest value of $\mathrm{R}^{2}$ and the lowest values of $\chi^{2}$ and RMSE.

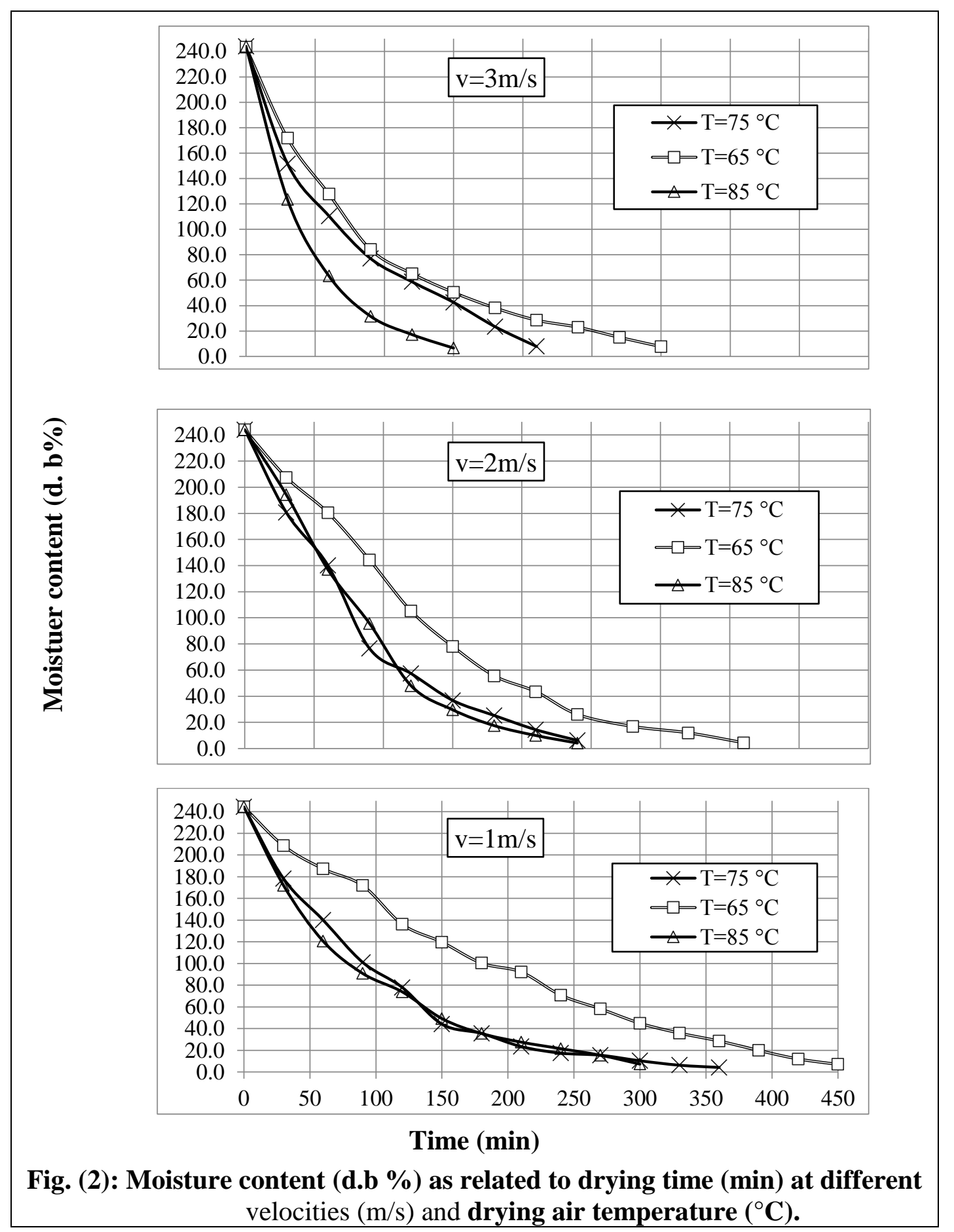


Generally $\mathrm{R}^{2}, \chi^{2}$ and RMSE values of the selected model in all experiments were varied between 0.989 and 1, 1.2E-32 and 8.3E-32, 6.74E-34 and 1.06E-17, respectively. Accordingly, the Henderson and Pabis. model was selected as the suitable model to represent the thin-layer drying characteristics of pomegranate peel.

TABLE (3) Drying rate constants.

\begin{tabular}{|c|c|c|c|c|}
\hline \multicolumn{2}{|c|}{ Model } & Lewis & \multicolumn{2}{c|}{ Henderson and Pabis } \\
\hline $\begin{array}{c}\text { Temperatu } \\
\text { re }{ }^{\circ} \mathbf{C}\end{array}$ & $\begin{array}{c}\text { Velocit } \\
\text { y m/s }\end{array}$ & K & K & a \\
\hline \multirow{3}{*}{$\mathbf{6 5}$} & 1 & 0.006 & 0.002 & 0.50 \\
\cline { 2 - 5 } & 2 & 0.009 & 0.0024 & 0.53 \\
\cline { 2 - 5 } & 3 & 0.013 & 0.003 & 0.37 \\
\cline { 2 - 5 } 75 & 1 & 0.01 & 0.003 & 0.34 \\
\cline { 2 - 5 } & 3 & 0.014 & 0.004 & 0.43 \\
\hline \multirow{3}{*}{$\mathbf{8 5}$} & 1 & 0.016 & 0.004 & 0.42 \\
\cline { 2 - 5 } & 2 & 0.014 & 0.003 & 0.44 \\
\cline { 2 - 5 } & 3 & 0.018 & 0.005 & 0.36 \\
\hline
\end{tabular}

\section{Drying constants:}

Table (3) shows the drying constants values (K) and (a)obtained at different temperatures and air velocities of pomegranate peel. It is noted that the $(\mathrm{k})$ and $(\mathrm{a})$ values have been steadily increasing with the increase in both temperatures and air velocities. Figs (3) reveal the relation between $(\mathrm{K})$ and $(\mathrm{v})$ at different $(\mathrm{T})$ the figure shows that the relation between $(\mathrm{v})$ and $(\mathrm{K})$ model lewis was linear relation as:

$$
K=a v+b
$$

Table (3) and Fig (4) show the relation between parameter a, b and T it's clear that the relation was linear equation as:

$$
b=0.003 T-0.019
$$

From equation (8) and (9) the relation was as following:

$$
K=0.004 v+0.003 T-0.019 \quad R^{2}=0.947
$$

Table (4): Parameters (a) and (b) at different air velocity (v).

\begin{tabular}{|c|c|c|}
\hline Temperature $^{\mathbf{0}} \mathbf{C}$ & $\mathbf{B}$ & $\mathbf{a}$ \\
\hline 65 & 0.0023 & 0.003 \\
\hline 75 & 0.007 & 0.003 \\
\hline 85 & 0.009 & 0.0035 \\
\hline
\end{tabular}




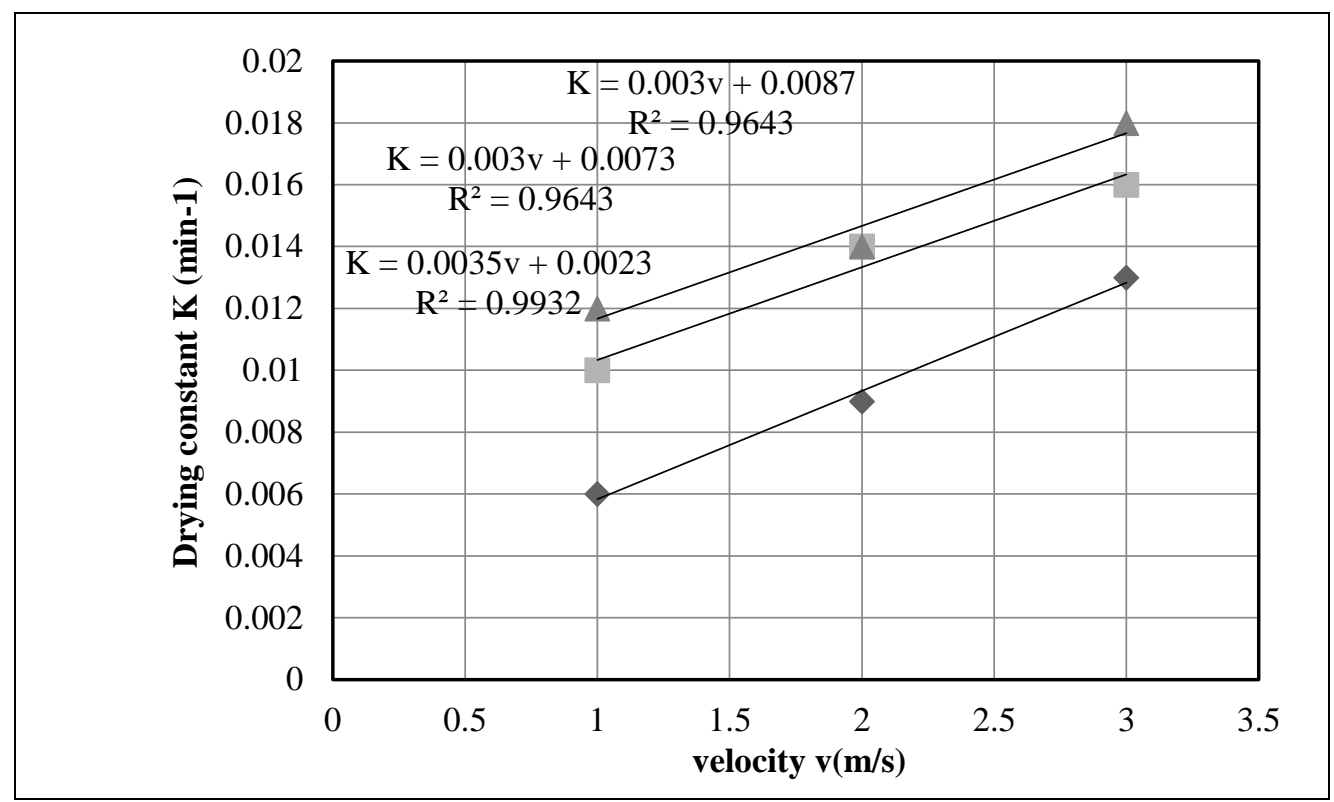

Fig. (3): The relation between drying air velocity $(\mathrm{m} / \mathrm{s})$ and drying constant $(\mathrm{K})$ at different drying temperature $\left({ }^{\circ} \mathrm{C}\right)$.

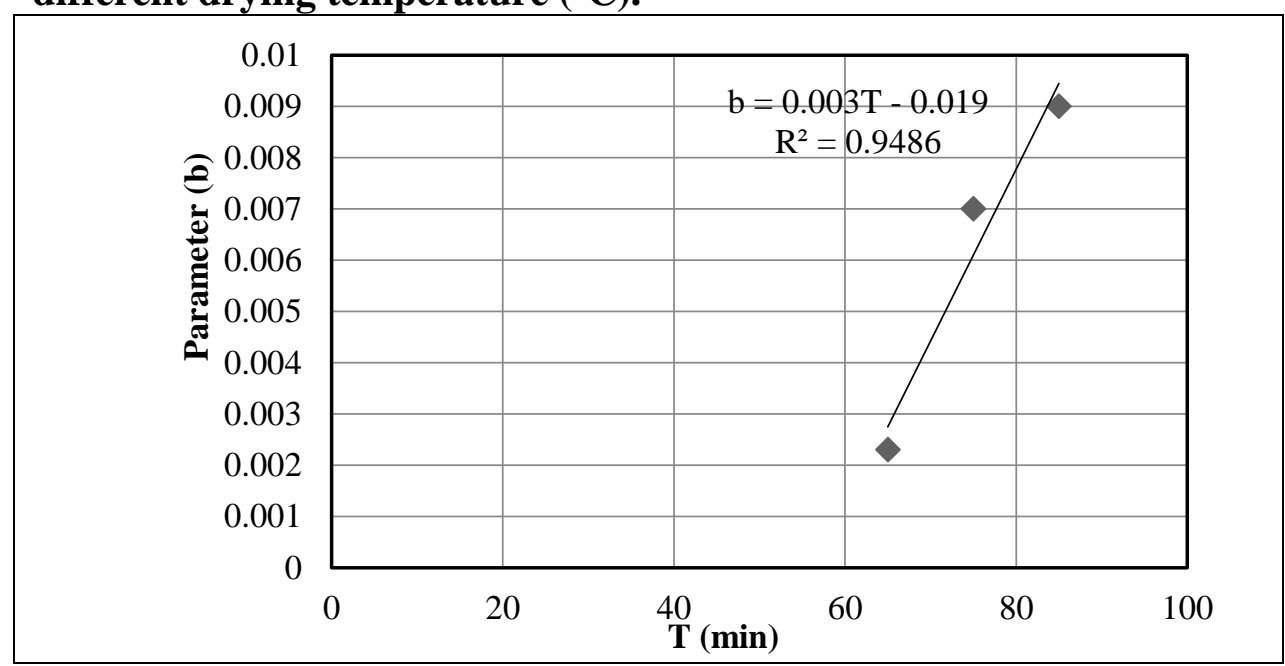

Fig. (4): Relation between parameter (b) and air velocity $\mathbf{v}(\mathrm{m} / \mathrm{s})$.

From equation (10) and model lewis the relation was as following:

$$
M R=e^{-(0.004 v+0.003 T-0.019) t}
$$

\section{Chemical analysis:}

Crude protein, lipids (Ether extract), ash and crude fiber contents of pomegranate peel and seeds powders were determined according to the procedures of the AOAC. (2000). The chemical analysis of pomegranate by-products based on dry basis. The result of analysis from pomegranate peel powder showed that the ash(4.4\%), fat $(1.8 \%)$, crude fiber $(16.6 \%)$, and Protein were $(5.84 \%)$ at dried air temperature of $85^{\circ} \mathrm{C}$ and Air velocity $3 \mathrm{~m} / \mathrm{s}$.

\section{Costs analysis:}

The operating cost (LE / $h$ ) for the convection dryer and the costs of kilogram dried product for pomegranate by-product by equation (6) and (7). The costs for were calculated at the drying conditions that achieved less drying time. The operating cost of convection dryer was $1.9 \mathrm{LE} / \mathrm{h}$ 
and the cost of kilogram dried product 5.5LE/kg at dried air temperature of $85{ }^{\circ} \mathrm{C}$ and Air velocity $3 \mathrm{~m} / \mathrm{s}$, while the price of $1 \mathrm{~kg}$ of dried pomegranate peel is $35 \mathrm{LE}$ in the market.

\section{CONCLUSION}

The drying process took place in the falling-rate period. With the increase of the drying temperature and drying air velocity, the moisture ratio decreased and the drying rate increased. Among the two tested model, the Henderson and Pabis model predicts and describes the drying process more accurately than others.

\section{REFERENCES}

Abd El-wahhab, G. G, (2015). Some engineering factors affecting fish By-Products recycling. M.Sc. Dep. of Ag. Eng., Fac. of Agric., Azhar U., 42-55.

AOAC, (Association Of Official Analytical Chemists) (2000). Official Methods Of Analysis Of The Aoac International, $17^{\text {th }}$ Ed. Gaithersburg, Marylad, Usa.

AOAC, (2005). Official Methods of Analysis, International Maryland, USA.

Awady, M. N.;. Yehia, L.; Ebaid, M. T. and Arif, E. M. (2003). Development and theory of rice cleaner for reduced impurities and losses, Misr J. Ag. Eng., 20 (4): 53 - 68.

Chen, H., Zhang, M., Fang, Z. And Wang, Y. (2013). Effects of different drying methods on the quality of squid cubes. Dry. Technol. 31, 1911-1918.

Doymaz, I., (2011) Experimental Study on Drying Characteristics of Pomegranate Peels, Food Sci. Biot. 20(4):965-970 (2011).

Faria A. and Calhau, C.(2010), Pomegranate in human health: An overview. pp. 551-563. In: Bioactive Foods in Promoting Health: Fruits and Vegetables. Watson RR, Preedy VR (eds). Academic Press, Amsterdam, Netherlands (2010).

Fawole, O. A.; Makunga, N.P., and Opara, U.L.(2012). antioxidant andtyrosine-inhibition activities of pomegranate fruit peel methonolic extract, BMC Complem. Altern. Med. 12 (2012) 200-225.

Fawole, O.A.; Opara, U.L. and Chen, L. (2015). Bioaccessibility of total phenolic concentration and antioxidant capacity of pomegranate fruit juice and marc after in vitro digestion, Acta Hortic. 1079 (2015) 285-290.

Hasnaoui, N.; Wathelet, B. and Ana Jimenez-Araujo (2014). Valorization of pomegranate peel from 12 cultivars: Dietary fiber composition antioxidant capacity and functional properties. Food Chemistry, 160, 196-203.

Henderson S.M. and Pabis S.,(1961). Grain drying theory. II. Temperature effects on drying coefficients. J. Agric. Eng. Res., 1961, 6, 169-174.

Karaaslan, S.; Erdem, T. And Oztekin, S. (2013). Mathematical modelling and color characteristics of purslane (Portulace oleraceae L.) leaves using different drying methods. Philipp. Agric. Scientist 96, 267-274. 
Lewis, W. K. (1921). The rate of drying of solid materials. J. of Industrial Eng., 5(13): 427 433.

Lopez, A.; Iguaz A.; Esnoz A. and Virseda P., (2006). Thin layer drying behaviour of vegetable wastes from wholesale market. Dry. Technol. 18: 995-1006.

Ministry Of Agriculture (2019). https://www.agrinewz.com/2020/07/

Mphahlele, R. R.; Pathare, P. B. and Opara, U.L.(2019). Drying kinetics of pomegranate fruit peel (cv. Wonderful), Scientific African 5 (2019) e00145, https://doi.org/10.1016/j.sciaf.2019.e00145

Perea-Flores, M.J.; Garibay-Febles, V.; Chanona-Pérez, J.J.; Calderón-Domínguez,G.; Méndez-Méndez,J.V.; Palacios-González, E. And Gutiérrez-López, G.F. (2012). Mathematical modelling of castor oil seeds (Ricinus communis) drying kinetics in fluidized bed at high temperatures. Ind. Crop. Prod. 38, 64-71.

Shabtay, A.; Eitam, H.; Tadmor, Y.; Orlov, A.; Meir, A.; Weinberg, P.; Weinberg, Z.G.; Chen, Y.; Brosh, A.; Izhaki, I..; Kerem, Z. and Agric, J.(2008). Nutritive and Antioxidative Potential of Fresh and Stored Pomegranate Industrial Byproduct as a Novel Beef Cattle Feed. J. Agric. Food Chem. 2008, 56, 10063-10070.

Tayel, S. A.; Ghanem, T.H.; El-Messery, A. A. and Badr, M. M. (2012). Modeling A Microwave/Convection Dryer for Drying of Potato Slices. Misr J. Ag. Eng., 29 (4): $1377-1398$.

Viuda-Martos, M.; Ruiz-Navajas, Y.; Martin-Sánchez, A.; Sánchez-Zapata, E.; Fernández-López, J.; Sendra, E.; Sayas-Barberá, E.; Navarro, C. And PérezÁlvarez, J.A. (2012). Chemical, physico-chemical and functional properties of pomegranate (Punica granatum L.) bagasses powder co-product. J. Food Eng. 110, 220-224.

Zielinska, M. And Markowski, M. (2010). Air drying characteristics and moisture diffusivity of carrots. Chem. Eng. Process 49, 212-218. 


\section{تجفيف طبقة رقيقة من مخلفات قشر الرمان}

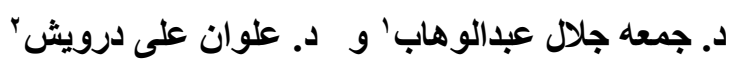

' مدرس ـ قسم هندسة المنشآت الزر اعية والتحكم البيئي ـ كلية الهندسة الزر اعية ـ جامعة الأزهر بالقاهرة ـ مصر.

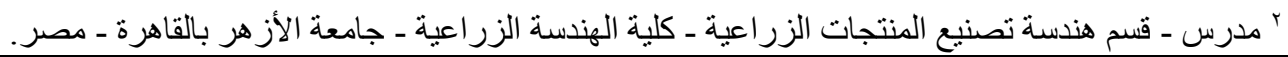

\begin{tabular}{|c|c|}
\hline 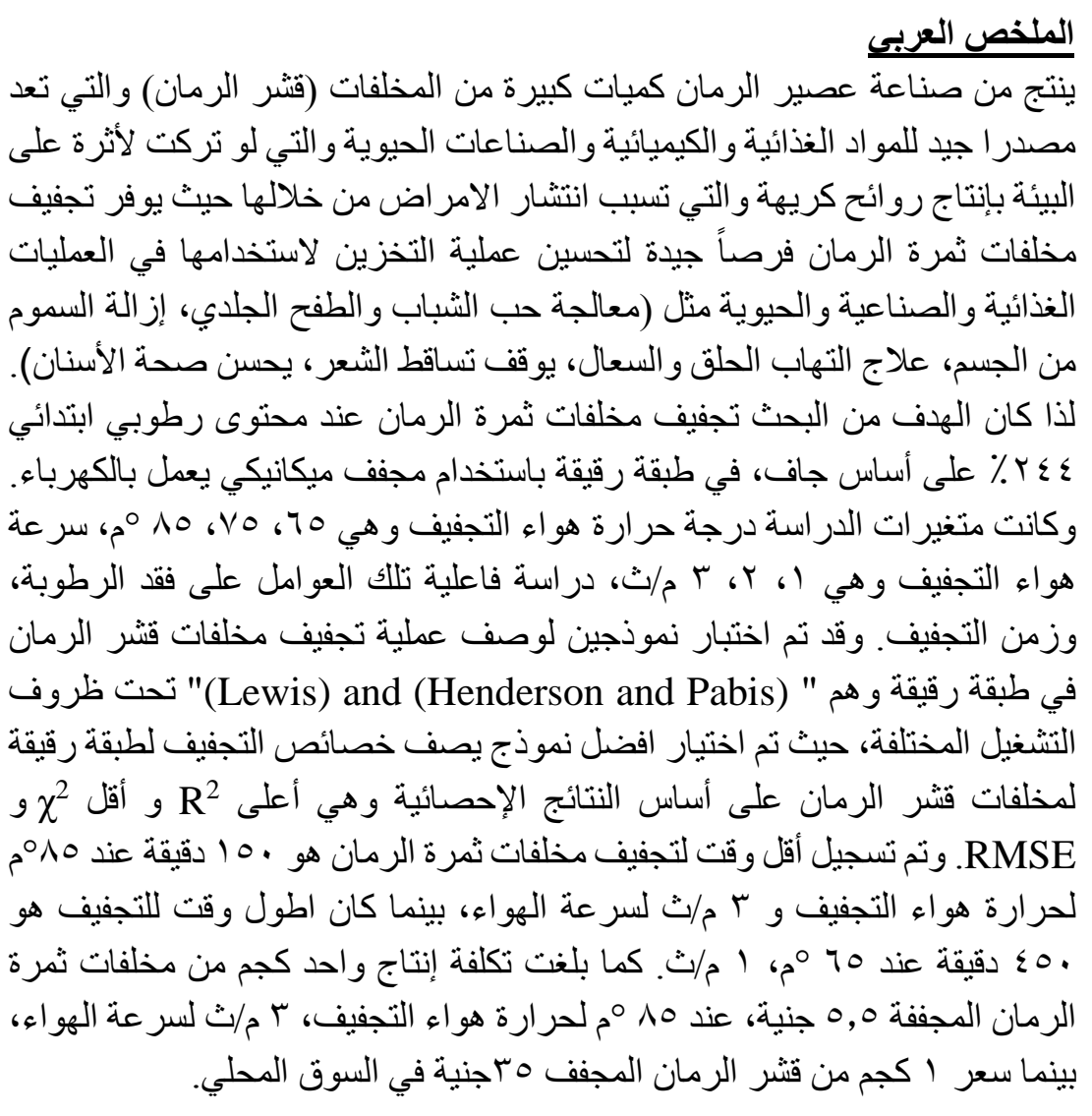 & 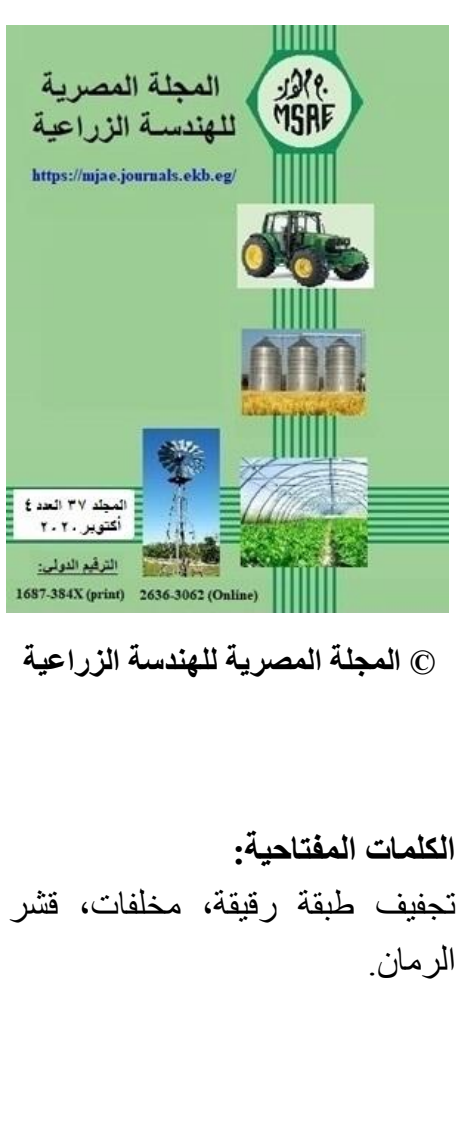 \\
\hline
\end{tabular}

